\title{
The Mass Effect of Supergiant Aneurysms
}

\author{
Süperdev Anevrizmaların Kitle Etkisi
}

\author{
Süha Türkmen', Umut Eryiğit' , Aynur Şahin', Selman Yeniocak², Abdülkadir Gündüz \\ 'Department of Emergency Medicine, Faculty of Medicine, Karadeniz Technical University, Trabzon, Turkey \\ ${ }^{2}$ Clinic of Emergency Service, Haseki Teaching and Research Hospital, İstanbul, Turkey
}

\begin{abstract}
A cerebral aneurysm larger than $25 \mathrm{~mm}$ in any plane is known as a giant aneurysm, and one greater than $60 \mathrm{~mm}$ as a supergiant aneurysm. Patients with aneurysms usually present with subarachnoid hemorrhage. However, a mass effect dependent on the aneurysm site and dimension may also be encountered in clinical practice. This case report describes a 72-year-old female patient with epistaxis and subsequent loss of consciousness and with a supergiant aneurysm. Epistaxis is a rare form of presentation of patients with supergiant aneurysms.
\end{abstract}

Keywords: Giant aneurysm, supergiant aneurysm, epistaxis Received: 16.11.2011 Accepted: 12.03.2012

\section{ÖZET}

Serebral anevrizmanın herhangi bir düzlemde boyutu 25 mm'den fazla ise dev anevrizma, 60 mm'den fazla ise süper dev anevrizma olarak adlandırılır. Anevrizmalı hastalar genellikle subaraknoid kanama kliniği ile başvururlar. Fakat anevrizmanın yeri ve boyutuna bağlı olarak kitle etkisinin oluşturduğu klinikle de karşımıza çıkabilirler. Bu vaka sunumunda epistaksis ve ardından bilinç kaybı gelişen, süper dev anevrizması olan, 72 yaşında bir bayan hastayı sunulmaktadır. Epistaksis süper dev anevrizması olan hastaların nadir bir başvuru şekli olabilir.

Anahtar Kelimeler: Dev anevrizma, süper dev anevrizma, epistaksis Geliş Tarihi: 16.11.2011 Kabul Tarihi: 12.03.2012

\section{Introduction}

Giant aneurysms represent 5\%-13\% of all aneurysms. If an aneurysm is larger than $25 \mathrm{~mm}$ in size it is known as a giant aneurysm, and as a supergiant if it exceeds $60 \mathrm{~mm}(1,2)$. Although most patients with aneurysm present with subarachnoid hemorrhage, they may also present with a mass effect depending on the location and dimensions of the aneurysm (3).

\section{Case Report}

A 72-year-old woman was brought in with sudden nosebleed and loss of consciousness developing some minutes thereafter. The patient was confused on arrival, with a Glasgow Coma Scale score of $11\left(E_{2^{\prime}} V_{4^{\prime}} M_{5}\right)$. Blood pressure was 190/100 mmHg, pulse $84 / \mathrm{min}$ and respiratory rate $22 / \mathrm{min}$. Nuchal rigidity was determined. Light reflex was +/- and we identified partial facial paralysis. The patient's epistaxis persisted, but was halted with the insertion of an anterior tampon. We learned that she had had hypertension for 20 years and had received treatment for this. Her history also revealed two intracranial aneurysms diagnosed 10 years previously. Surgery had been recommended for the aneurysms, but the patient had refused. Brain tomography (BT) with and without contrast and BT angiography were performed. Two bilateral giant aneurysms and subarachnoid hemorrhage were identified. Both aneurysms originated from the internal carotid artery. The aneurysm in the left hemisphere was $80 x 60$ $\mathrm{mm}$ in size, partially thrombosed and with surrounding calcifications. The aneurysm in the right hemisphere was $50 \times 40 \mathrm{~mm}$ in size (Figure 1). The aneurysm on the right was destroying the maxillary sinus, sphenoid bone and ethmoid cells (Figure 2). The patient was monitorized. The head of the bed was raised by 30 degrees in order to reduce intracranial pressure and mannitol $1 \mathrm{~g} / \mathrm{kg}$ IV was started. Oxygen at 4-6 I/min was administered. Since systolic arterial pressure was $>180 \mathrm{mmHg}$ and intracranial pressure was thought to have risen, parenteral antihypertensive therapy was started. For that purpose, esmolol in a loading dose of 500 microgram $/ \mathrm{kg} / \mathrm{min}$, followed by a maintenance dose of 50 microgram $/ \mathrm{kg} / \mathrm{min}$ was started. Surgery was planned by the brain surgery department. While the patient was under monitoring and treatment in brain surgery intensive care, sudden 


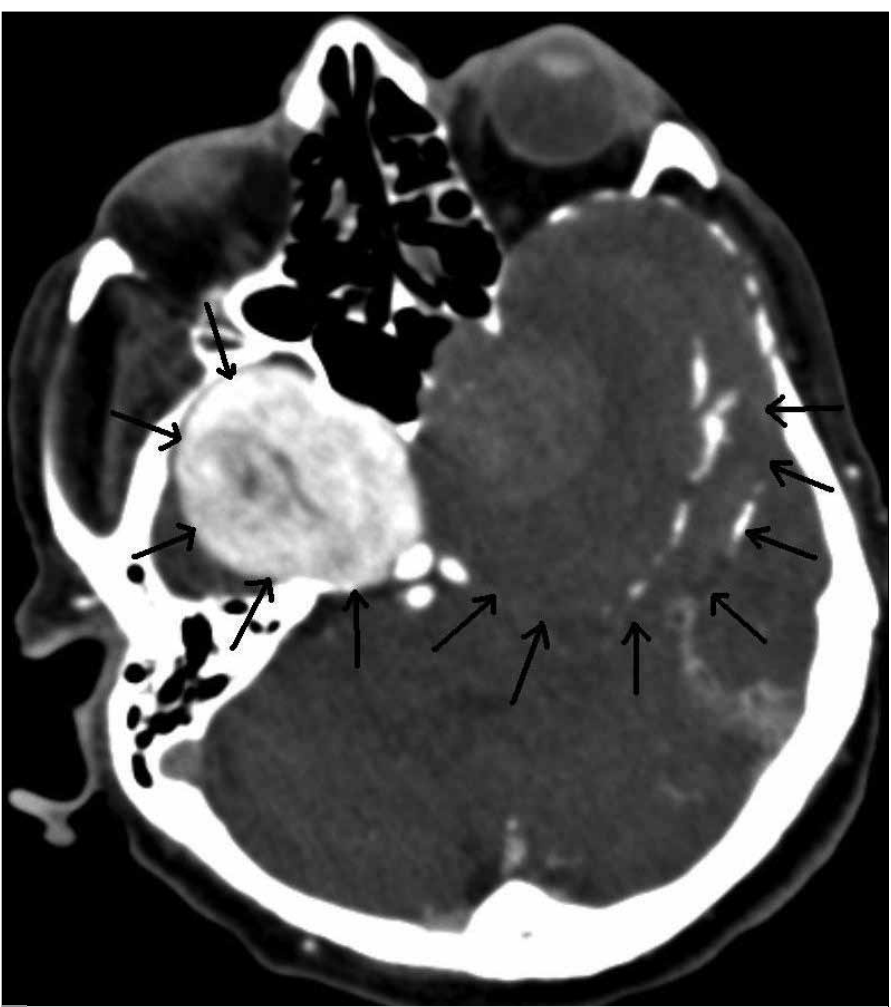

Figure 1. Bilateral aneurysm seen at contrast brain tomography. The aneurysm in the left hemisphere is partially thrombosed with surrounding calcifications

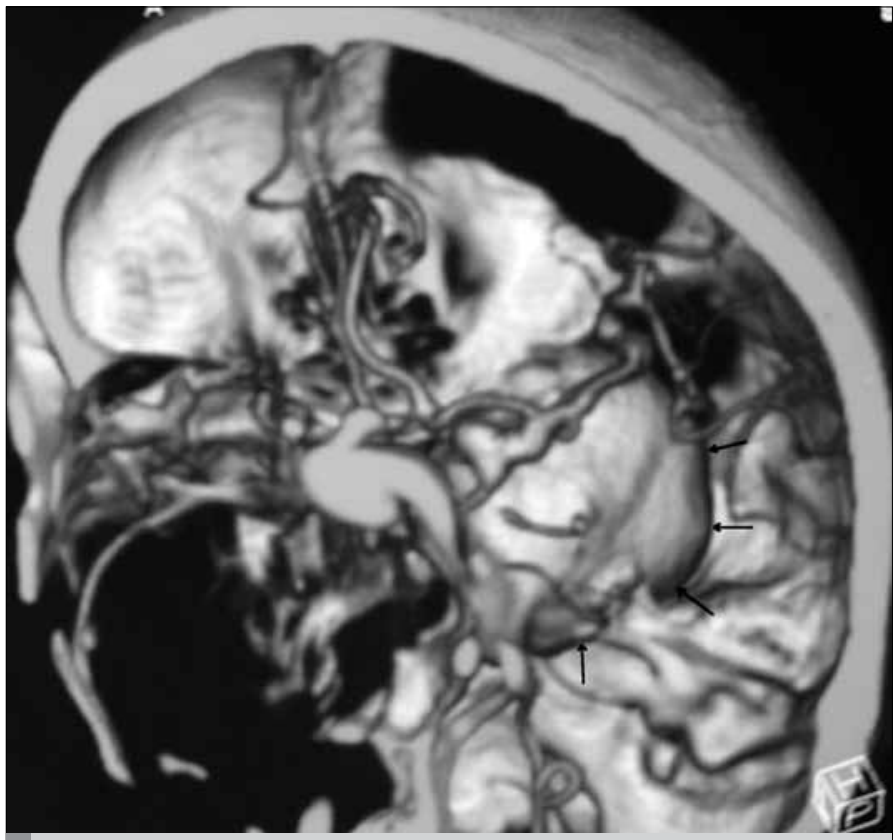

Figure 2. Destruction in the maxillary sinus, sphenoid bone and ethmoid cells caused by aneurysm at three-dimensional brain BT angiography

respiratory arrest developed. Appropriate cardiopulmonary resuscitation procedures were performed, but no response was obtained. The patient died $4 \mathrm{~h}$ after hospitalization.

\section{Discussion}

Subarachnoid hemorrhages represent $6 \%$ of all strokes and have a high mortality level of $45 \%$. The most frequent cause (85\%) of nontraumatic subarachnoid hemorrhage is intracranial aneurysmal rupture. Because of the turbulence at blood vessel bifurcations, aneurysms generally appear in the anterior part of Willis's polygon (4).

Patients with unruptured aneurysms are generally asymptomatic; the most common symptom is headache. Headache is again the most common symptom in subarachnoid hemorrhage resulting from ruptured aneurysm, and patients generally describe the t pain as the most severe they have experienced to date. Other frequently seen symptoms are nausea, vomiting, altered awareness, seizure, diplopia and nuchal rigidity (5). Epistaxis in subarachnoid hemorrhage is rare. However, two clinical findings of epistaxis were present in the case described here.

Aneurysms larger than $25 \mathrm{~mm}$ in size are known as giant aneurysms. These are generally seen in the cerebral artery, internal carotid artery and vertebrobasilar artery $(3,6)$. Giant aneurysms generally produce clinical findings in women and at more advanced ages (7). In contrast to small, saccular aneurysms, giant aneurysms produce clinical findings caused by the destructive lesion as a result of the spaceoccupying mass. Progressive cranial nerve, brain stem and cerebral hemisphere dysfunction, a progressive dementia picture, increased intracranial pressure, cerebral infarct findings and partial epileptic seizure occupy an important place among these (8).

Techniques such as BT, lumbar puncture, computerized tomography and magnetic resonance angiography are used for diagnostic purposes in subarachnoid hemorrhages. BT has 98\%-100\% sensitivity. Sensitivity is particularly high in the first $12 \mathrm{~h}$ after the onset of symptoms, falling to $93 \%$ after $24 \mathrm{~h}$. Lumbar puncture should be performed in patients when tomography is negative but the suspicion of subarachnoid hemorrhage persists (9).

Sudden clinical changes may be seen in patients with subarachnoid hemorrhage. These patients must therefore be closely monitored, and attempts made to protect against potential complications. Blood pressure control is important in this respect. Labetalol is the main antihypertensive agent of choice. Vasospasm is one important complication of subarachnoid hemorrhage, and can particularly be seen between the second day and the third week. Nimodipine has a proven protective effect against vasospasm, the recommended dosage being 360 mg/day. Pain control and antiemetic therapy are important. Seizures may be seen in subarachnoid hemorrhage, but prophylactic antiepileptic is not recommended (10).

Epistaxis is the most common ear-nose-throat emergency and generally results from trauma, hypertension, blood dyscrasia, anticoagulant therapy and, rarely, hereditary telangiectasia (11).

\section{Conclusion}

Epistaxis may rarely develop as a result of tissue destruction related to the nasal cavity. We describe a case a case of a supergiant aneu- 
rysm that may rarely be encountered in terms of dimensions and clinical onset.

\section{Conflict of interest}

No conflict of interest was declared by the authors.

\section{References}

1. Yasargil MG. Giant intracranial aneurysms. In Yasargil MG, MD, Editor. Microneurosurgery. 2nd ed. New York: Thieme-Straton; 1984.p.296-304.

2. Sundt TM, Piepgras DG, Fode NC. Giant intracranial aneurysms. Clin Neurosurg 1991; 37: 116-54.

3. Cahil DW. Supergiant anterior circulation aneurysms. Neurol Res 1992: 14: 204-7.

4. Coppadoro A, Citerio G. Subarachnoid hemorrhage: an update for the intensivist. Minerva Anestesiol 2011; 77: 74-84.
5. Fontanarosa PB. Recognition of subarachnoid hemorrhage. Ann Emerg Med 1989; 18: 1199-205. [CrossRef]

6. Francesco M. Giant aneurysm of pericallosal artery. Neurosurgery 1990: 26: 703-6. [CrossRef]

7. Barrow DL, Alleyne C. Natural history of giant intracranial aneurysms and indications for intervention. Clin Neurosurg 1995; 42: 214-44.

8. Ravi Kumar CV, Palur RS, Satish S, Rao BR. Vertebral artery aneurysms. Neurol India 2000; 48: 161-3.

9. Bhat AR, Afzalwani M, Kirmani AR. Subarachnoid hemorrhage in Kashmir: Causes, risk factors, and outcome. Asian J Neurosurg 2011; 6: 57-71. [CrossRef]

10. Hackman JL, Johnson MD, Ma OJ. Spontaneous subarachnoid and intracerebral hemorrhage. In Judith E. Tintinally, MD, MS, Editor. Emergency Medicine. 7th ed. New York: McGraw-Hill; 2011.p.1118-22.

11. Kotecha B, Fowler S, Harkness P, Walmsley J, Brown P, Topham J. Management of epistaxis: a national survey. Ann R Coll Surg Engl 1996; 78: 444-6. 